\title{
RNA Structure and Folding, edited by Dagmar Klostermeier and Christian Hammann. 2013. De Gruyter, Berlin/Boston.
}

Stephen A. Wainwright wrote in his book Axis and Circumference, The Cylindrical Shape of Plants and Animals a sentence, now frequently quoted, "Structure without function is a corpse, function without structure is a ghost." With the advances and amazing progress in structural biology and bioinformatics, the descriptions and discussions about relationships or correlations linking structure to function, and vice versa, belong inevitably to almost any biological publication. However, as a colleague, Marc van Regenmortel, mentioned once, "Structure-function, infernal duo, it dissociates every microsecond!" For tackling this conundrum, biophysical methods and tools, coupled with the concepts of thermodynamics, are necessary to obtain a global understanding of biological and biochemical phenomena.

The chapters in this book describe a whole gamut of techniques for assessing the biological reality and relevance of RNA structures and their molecular complexes. The large majority of our structural views on biological molecules comes from crystallography (celebrated this year since 2014 is the UNESCO International Year of Crystallography). However, we do see more frequently in the literature structures, surely beautiful and fascinating, but not necessarily biologically meaningful. RNA crystallography is probably highly prone to nonbiologically relevant structures or states because of multiple conformational states energetically accessible to RNA molecules. We need to remember only the striking saga of the hammerhead ribozyme structure, a prototypical example where excessively reductionist approaches by molecular biologists as well as structural biologists led the field astray for several years. Nowadays, we need to understand large complexes with several proteins and often several RNA strands. Proteins interact with each other in complex ways and, even without contacting the RNA component, require its presence for binding. The assembly of large ribonucleoparticles (RNPs) is therefore an interwoven and increasingly complex interplay between the protein and RNA parts. The biological relevance of the isolated complexes needs to be assessed regularly and at each step using a variety of techniques. Even after arduous and painstaking years of work, the crystallization and solution of the structure of an RNP complex demands that the biology it contains be ascertained.

Article and publication date are at http://www.rnajournal.org/cgi/doi/ 10.1261/rna.048322.114.
The book contains 15 chapters written by experts in the field. All of the chapters are presented in a common fashion with clear figures, several in color, and very readable formulae. The chapters can be grouped into five broad general methods. The first group covers the chemical approaches of RNA structure in solution: chemical probing (Mark Helm), bioorthogonal modifications (Claudia Höbartner et al.), and footprinting approaches (Mélodie Duval et al.). The second group covers the main biophysical techniques: optical spectroscopy and calorimetry (by the editors), the elegant experiments tractable by gel electrophoresis (David Lilley), the rich possibilities of fluorescence energy transfer (Airat Gubaev and Dagmar Klostermeier), and the more recent single-molecule approaches using optical tweezers (Mathilde Bercy et al.). The third group covers the magnetic resonance techniques: nuclear magnetic resonance (Christina Mozes and Mirko Hennig) and pulsed electron paramagnetic resonance (Ivan Krstic et al.). The fourth major group covers the structural techniques of X-ray diffraction and cryoelectron microscopy. There is first a refreshing chapter on crystallization of RNA (Adrian Ferré-D'Amaré). X-ray diffraction techniques as such are not described, but the use of X-ray diffraction coupled with atomic force microscopy (Alexander McPherson), small-angle X-ray scattering (Alexey Kikhney et al.), and cryo-electron microscopy (Jean-François Ménétret et al.) illustrates the power and novelty that can be reached in this way. Finally, in the last group, two chapters cover some bioinformatic approaches: one for the prediction of secondary structure (Gerhard Steger and Robert Giegerich) and another for searching and annotating three-dimensional structures (Anton Petrov et al.).

The book RNA Structure and Folding brings an up-to-date compilation of clear reviews with complete sets of references on most techniques regularly used to decipher the RNA structure and function. Students, researchers, and teachers should find it of great value.

Eric Westhof, Architecture et Réactivité de l'ARN, Institut de biologie moléculaire et cellulaire du CNRS, Université de Strasbourg, Strasbourg 67084, France; e-mail: e.westhof@ ibmc-cnrs.unistra.fr

(C) 2014 Westhof This article is distributed exclusively by the RNA Society for the first 12 months after the full-issue publication date (see http:// rnajournal.cshlp.org/site/misc/terms.xhtml). After 12 months, it is available under a Creative Commons License (Attribution-NonCommercial 4.0 International), as described at http://creativecommons.org/licenses/by-nc/4.0/. 

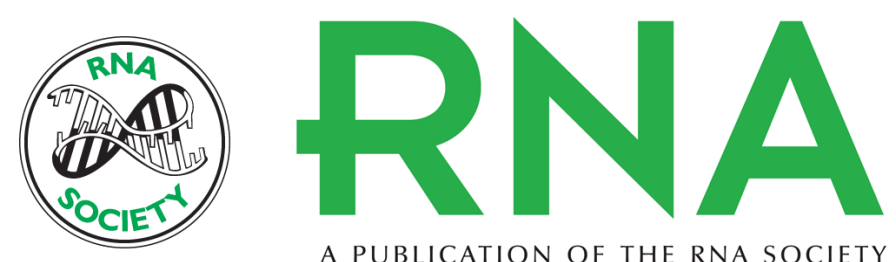

A PUBLICATION OF THE RNA SOCIETY

\section{RNA Structure and Folding, edited by Dagmar Klostermeier and Christian Hammann. 2013. De Gruyter, Berlin/Boston.}

Eric Westhof

RNA 2014 20: 1843

\begin{tabular}{cc}
$\begin{array}{c}\text { Creative } \\
\text { Commons } \\
\text { License }\end{array}$ & $\begin{array}{c}\text { This article is distributed exclusively by the RNA Society for the first } 12 \text { months after the } \\
\text { full-issue publication date (see http://rnajournal.cshlp.org/site/misc/terms.xhtml). After } 12 \\
\text { months, it is available under a Creative Commons License (Attribution-NonCommercial } \\
4.0 \text { International), as described at http://creativecommons.org/licenses/by-nc/4.0/. }\end{array}$ \\
$\begin{array}{c}\text { Email Alerting } \\
\text { Service }\end{array}$ & $\begin{array}{l}\text { Receive free email alerts when new articles cite this article - sign up in the box at the } \\
\text { top right corner of the article or click here. }\end{array}$ \\
\hline
\end{tabular}

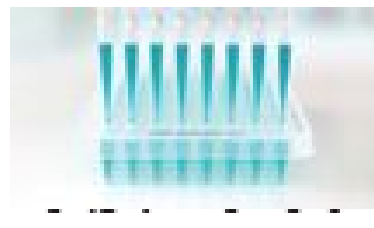

Providing Precise Solutions for your research.

To subscribe to RNA go to:

http://rnajournal.cshlp.org/subscriptions

C 2014 Westhof; Published by Cold Spring Harbor Laboratory Press for the RNA Society 